\title{
Video-feedback Intervention to promote Positive Parenting and Sensitive Discipline as a new psychological method of development support in Poland
}

\begin{abstract}
This article will introduce a new method that has been available in Poland since 2015, based on video recordings, for families with children up to 5 years of age - the Video-feedback Intervention to promote Positive Parenting and Sensitive Discipline (VIPP-SD) (Juffer, Bakermans-Kranenburg, van IJzendoorn, 2008).

The authors first discuss the current framework of development support psychology in Poland. Next, there is a review of methods based on video training. General information about the VIPP-SD intervention program is presented in the following part of the paper, focusing on international evidence-based studies supporting the effectiveness of the method. The need for a cultural adaptation and implementation of the VIPP-SD program in Poland is outlined.
\end{abstract}

Key words: development support, video-feedback interventions, Video-feedback Intervention to promote Positive Parenting and Sensitive Discipline, VIPP-SD

\section{Introduction}

The goal of this paper is to perform a review of psychological methods based on video techniques in the context of supporting the development of toddlers and their families. However, the main goal of the authors is to signal that there is a new method of psychological support for families and small children that has been available in Poland since 2015 - the Video-feedback Intervention for Positive Parenting and Sensitive Discipline (VIPP-SD) (Juffer, Bakermans-Kranenburg, van IJzendoorn, 2008).

To this end, the authors will first discuss the general theoretical background of development support psychology in Poland. Next, the authors will perform a synthetic review and description of methods based on video training, with an emphasis on the psychological support of development of toddlers and the functioning of their families in the context of realisation of socialising functions and education. The basic assumptions of the VIPP-SD intervention program are then presented, focusing on international evidence-based studies supporting its effectiveness. The long-term goal underlying this paper is to signal that work should begin on the cultural adaptation and implementation of the VIPP-SD method in Poland.

\section{Psychology of development support - presentation of the current theoretical background in Poland}

Recently the term "development support" has become an increasingly popular, broad and flexible term, and it is understood in very different ways by people using it in different contexts - both colloquial and specialist. It seems that the term has entered the common language for good.

While illustrating this background the authors intend to argue that "development support", like many other terms derived from social sciences, is in danger of becoming blurred. The abuse of the term also applies to areas involving the implementation of development support methods, including video training - which is the main subject of discussion later on in this paper.

In general, we observe an escalating situation in which everyone supports everything using different methods in Poland. This leads to the need for a synthetic terminology to be agreed upon, as well as a review of the background of the current objective knowledge about the process of development support in Polish psychology. It's not only non-specialists who may feel lost in this confusing terminology chaos. Anna Brzezińska, one of the precursors of development support in scientific psychology, elaborated on considerations about answering the following question

\footnotetext{
* Institute of Psychology, Kazimierz Wielki University, Bydgoszcz
} 
during her lecture in the Institute of Psychology in Bydgoszcz in 2012: is development support a form of or the basis of psychological help?

Thus, it is worth remembering that the term "development support" originated in the social sciences and in Poland was discussed most extensively in the context of psychology and pedagogy (Bogdanowicz, 2010 and others; Brzezińska, 2005; Kaja, 2010 and earlier). Its considerations are dominated by social sciences where 'the eternity of development, self-realisation and (...) the meaning of life is emphasised' (Kaja, 2004, p. 21).

Maria Kielar-Turska (2003) performed an in-depth analysis of semantic fields for the term "development" and related terms. Currently, the most popular three related terms are: development support, development assistance and early intervention/early development support. Because development support is the most general term, the review of approaches leading towards more specific areas of implementation of supportive actions for small children or children with disabilities will start with this one.

In general, development support is defined in categories of forms and methods of psychological help aimed at the psychological stimulation and/or psychological correction aimed at individuals who, for various reasons, may need such help (Brzezińska, 2005; Kaja, 2010). This form of help is used when 'prior development and related processes (education, socialisation) were problematic and this, or other factors such as critical experiences, has caused problems disrupting the life of the individual' (Kaja, 2010, p. 33).

The highest level of sophistication of theoretical considerations in Poland can be found in Barbara Kaja's proto-theory, informed by years of scientific and practical activity, which proposes a Humanistic Model of Development Support (2010). This model is based on a coherent and refined idea which defines, in detail, the process of development support as a string of intentional actions aimed at allowing the supported person to solve the tasks and life problems on their own. The essence of development support is a special type of human interaction that is directed at a person acting in life and searching for meaning in life, and it includes assisting them in these efforts through helping them develop their skills and qualifications (Kaja, 2010, p. 32-33). At the root of this approach lie previous ideas with similar assumptions (Kielar-Turska, 1997; Straś-Romanowska, 2003). According to Kaja's postulate, development support psychology has the prerequisites of a scientific discipline (2010).

In attempting to make the term "development support" more specific, it is worth mentioning the three main criteria defining the approaches postulated by different authors. These are: 1 . The characteristics of the recipients of the supportive actions, 2 . the characteristics of the performers of the support, and 3. the way the development support process is performed.

Key characteristics defining the recipients of supportive actions include indications of the specifics of one's development with an emphasis on the current stage of development. This results in a distinction between actions aimed primarily at children and youth (Bodganowicz, 2010 and others; Obuchowska, 1993, 1997; Gruszczyk-Kolczyńska, 2003 and others; Puślecki, 2008; Pilecka, 2012); and those targeting such actions at people regardless of the present state of their development (Brzezińska, 2005; Kaja, 2010; Kielar-Turska, 1992; Kowali, 2000; Straś-Romanowska, 2003). On the other hand, Brzezińska (2005) proposed a definition of recipients which focuses on whether the intervention is targeted at a single individual or entire groups of people (or even societies).

The second criterion is related to the performers of supportive actions - whether they ought to be a specialist (psychologist, pedagogue, speech therapist, physiotherapist) (Gruszczyk-Kolczyńska, 2003 and others; Gruszczyk-Kolczyńska, Zielińska, 2000, 2004; KielarTurska, 1992; Obuchowska, 1993; Puślecki, 2008) or there is no need for specialist knowledge (Kaja, 2010; Brzezińska, 2005; Pilecka, 2012; Straś-Romanowska, 2003). It is worth noting that among authors who allow supportive actions to be performed by non-specialists, there is an agreement that these performers have to be reflexive and can take conscious responsibility for the undertaken actions. In the context of further considerations of video-based techniques of development support, it is important to point out that such non-specialists could be, and often are, parents, or even grandparents (cf.: wardowski, 2012). This can be effective as long as it is conducted under professional supervision.

The third criterion defining the theoretical concepts of development support is the way in which supportive actions are performed. The main factor differentiating the forms of development support is its course, with an emphasis on its harmony and tempo (Trempała, 2014). Based on the course of the development, two groups of concepts can be distinguished: concepts mainly concerning corrective psychological intervention in case of developmental disorders (Bogdanowicz, 2010 and others; Gruszczyk-Kolczyńska, 2003; Pilecka, Pilecki, 1996; Twardowski, 2012), and concepts allowing for psychological stimulation actions aimed at people characterised by a normative course of development in order to optimise their functioning and/or to realise their potential and perfect their talents (Kaja, 2010; Brzezińska, 2005; Kielar-Turska, 1992; Obuchowska, 1997; Straś-Romanowska, 2003; Puślecki, 2008). It ought to be stressed that this type of supportive action nowadays falls within the domain of a new discipline in psychology positive psychology (Carr, 2009; Czapiński, 2005).

The form of development support also depends on the main area of intervention. The goal can be simply to help an individual to make a full use of their personal resources and improve their overall functioning (Obuchowska, 1997) or it can be more specific, such as coping with adversities (Brzezińska, 2005; Kaja, 2010), supporting cognitive development and the education process (Gruszczyk-Kolczyńska, 2003), or focusing actions on a specific area of development or intellectual functioning which requires particular support (Kielar-Turska, 1992). 
We can also distinguish between the forms of supportive actions that can be either direct or indirect that is, targeted either directly at the recipient or at their environment (Brzezińska, 2005).

Because of this, the aforementioned definitions of early intervention and/or early development support can be treated as a specific form of supportive actions. These definitions are mainly used in the context of working with small children and their families and/or children with disabilities (Pilecka, Pilecki, 1996; Pilecka, 2012; Twardowski, 2012). There is a convention that that in the case of children with disabilities the term "intervention" is related to the medical and rehabilitation actions while "support" is usually used to describe psychological interventions.

Concluding the above attempt to briefly systematise the term "development support" and related terms, in the context of the considerations of this paper it is necessary to point out that the methods of psychological actions based on video techniques are becoming increasingly popular. These mainly include Video Home Training (VHT) and its variants, which have been known in Poland since the nineties (Miś, Kujawa, Frysztacki, 1999), and the new psychological method which has been available in Poland since 2015 - The Video-feedback Intervention to promote Positive Parenting and Sensitive Discipline (VIPP-SD). The goal of the subsequent part of this paper is to provide a detailed description and evaluation of these methods. One of the main areas of their implementation is parenting, both in the context of providing additional support in cases of normal development and in the context of supporting families that (for various reasons) are at risk of educational problems.

\section{Methods of development support based on video techniques}

\section{Video Home Training (VHT)}

Video Home Training was developed in the eighties in the Netherlands by Harm Biemans and Maria Arts (1988, 1990). The researchers observed that if a family analyses their video recordings, then the functioning of that family's (such as interaction with the children) improves. Biemans, together with a team of researchers from the Netherlands (Biemans, Hoogland, 1988), were inspired by the work of ethnologists Colwyn Trevarthen et al. $(1978,1979)$ at Edinburgh University, who studied successful interactions between infants and their mothers. Trevarthen found that the mother's responsiveness to her baby's initiatives developed intersubjectivity (or a shared understanding), which is the basis of all effective communication, interaction and learning. He created a list of favorable verbal and nonverbal behaviors (the Basic Contact Principles - Trevarthen, Hubley, 1978) that parents should exhibit to improve a child's opportunities for development. These principles were fundamental to Video Interaction Guidance and are known as the principles for attuned interactions and guidance (Kennedy, Landor, Todd, 2010).
Initially, VHT was developed in order to support parents in guiding their children to develop desired qualities. It was then shown that these methods also lead to conflict prevention, support healthy social, emotional and cognitive development, improve the quality of communication, and build good relationships in general (Miś, Kujawa, Frysztacki, 1999). Therefore, this intensive form of assistance for families with social issues was also implemented in other areas where there is a need to improve communication, establish proper interpersonal relationships, enhance one's control over their own life or to prepare for work in a given social field. Depending on the line of work of the practitioners, video training has various names. In Poland, Video Home Training is called Video Intervention Training (VIT), or sometimes Video Training Communication (VTC) (see: Miś, Kujawa, Frysztacki, 1999). While in the UK and other European countries Video Home Training (VHT) is more often called Video Interaction Guidance (VIG) (see: Kennedy, Landor, Todd, 2010) and is widely used by institutions supporting people with social or family issues, including teachers, nurses, social workers or other family support staff who work directly with families.

\section{Description of the video training method}

Harry Biemans et al. (1989), applied Trevarthen's "Basic Contact Principles" and created VIG. VIG consists of the principle of basic communication - that successful interaction between parents and their children is the basis for the formation of positive behavioural patterns within the whole family. The way that VIG is applied (during the video training) is based on the recorded material. A video recording can be made at home by parents with children or by caregivers taking care of their client in an institution. A personalised analysis of the material is performed afterwards.During each home visit about 10-20 minutes of video material is recorded, after which a trainer or coach shows and explains selected examples of positive contact between wards and their caregivers from the material recorded during the previous visit. The video training program may help parents to improve their interaction with children, and help caregivers to improve their interactions with their wards. VIG provides necessary knowledge and supports acquiring new skills in the field of communication in the family (e.g. positive reactions to a child's behavior). Focusing on the positive experience provides parents or caregivers with a sense of security and acceptance of their efforts as they interact with the child. Providing support to a family in both domestic and outdoor situations together with their active participation in analysing the video recordings encourages parents to independently seek new, better ways of handling their own children.

\section{Evaluation of the video training method}

Video training was found to be a very effective tool in working with single, drug-abusing, malfunctioning mothers, whose young children are at risk (Biemans, 1990). Analysis of parent-child communication processes is also particularly important when development is disrupted. In 
such situation, it is vital to support caregivers (parents, therapists, teachers) in reading the child's signals and responding adequately to them.

Other studies show that video home training may have many positive effects on families' health and interactions. Families achieved their goals related to parenthood, relationships between partners, as well as childcare and child-rearing skills. VHT can be recommended for providing families with early support, as well as anticipating and preventing problems in family-life. For example, HäggmanLaitila, Pietilä, Friis, and Vehviläinen-Julkunen (2003), discovered that video training may be used as a method of early support in dealing with issues associated with control in family life. The process of videotaping family life, the in-depth analysis of the videotapes, recognition of instances of successful interaction, and the search for new alternatives gave participants the feeling that they could make their everyday life more efficient and functional. It has been shown that video training helped families have better control over their lives.

Video training is effective in households where, for various reasons, proper communication has been disrupted or never had the opportunity to develop. It is effective when working with families with various problems where parents, because of a lack of positive communication models or due to pressure associated with poverty or insufficient education, failed to build a proper relationship with their children. The literature emphasizes that "it can bring true relief and symptomatic improvement" (the reduction of anxiety, inner tension, and somatic symptoms) (see Miś, Kujawa, Frysztacki, 1999).

Because of the specific and interactive nature of the method, video training is also applicable to family nursing. It fosters the realization of family-centeredness and family orientation (Häggman-Laitila, Seppänen, VehviläinenJulkunen, Pietilä, 2010). Other researchers, examined the effectiveness of VIG adjunct to standard hospital care. The results indicate that VIG reduces the possible negative impact of preterm birth on the parent-infant relationship. The positive effects of VIG were particularly strong in mothers and fathers of infants born preterm (25-37 weeks of gestation) and who experienced the preterm birth as very traumatic (Eliëns, 2010; Kennedy, Landor, \& Todd, 2010).

Studies of the video training program conducted in recent years demonstrated that VIG significantly changed the emotional and behavioural aspect of dealing with difficulties among the children who received the service. Video interventions may have positive effects on professional caregivers of children and adults with visual and intellectual disabilities (Damen, Kef, Worm, Janssen, Schuengel, 2011). It can also be helpful for professional caregivers with no autonomous attachment representations (Schuengel, Kef, Damen, Worm, 2012). Therefore, video training is a tool that may be successfully used not only by families, but also by professional caregivers in facilities like care centres, nursing homes, hospitals, schools, prisons, and other resocialization institutions.

In conclusion, video training is used in more than 15 countries and by at least 4000 practitioners around the world (Miś, Kujawa, Frysztacki, 1999; Kennedy, Landor, Todd, 2010). The use of video training led to the improving competences of parents (or caregivers), as well as an increase in the self-confidence of parents who took part in the process of supporting the development of their children. For the aforementioned professionals, it is recommended to encourage implementation of video training as a tool to enhance communication between people and to improve their own leadership, supervisory and team building skills. It's vital to emphasize that video training can be applied to target the needs of a much wider range of people than those for whom it was originally intended. Hence, in the next section, another method of video intervention is going to be presented. It is called Video-feedback Intervention to promote Positive Parenting (VIPP). This method was inspired by Trevarthen's (1978) and Bierman's (1990) assumptions on mother-child interaction, and refers to the theory of attachment.

\section{Video-feedback Intervention to promote \\ Positive Parenting and Sensitive Discipline (VIPP-SD)}

The Video-feedback Intervention to promote Positive Parenting and Sensitive Discipline (VIPP-SD) was developed at the Centre for Family Studies in Leiden University in the Netherlands by Femmie Juffer, Marian Bakermans-Kranenburg and Marinus H. van IJzendoorn (2008). The method integrates two theories: the attachment theory of John Bowlby (1969) and Mary Ainsworth (1974), and the coercion theory of Gerald Patterson (1982). Attachment theory suggests that a child's present and subsequent development is optimal when they treat their parent(s) as: "the secure base from which they can explore the world, and the safe heaven to which they can return for comfort and protection in times of need" (Ainsworth, 1974; Bowlby, 1969, see: Juffer, Bakermans-Kranenburg, van IJzendoorn, 2008, p. 37). Taking as a starting-point the positive child development outcomes related to secure attachment as well as studies supporting sensitive parenting, (e.g., De Wolfe \& van IJzendoorn, 1997) this method of intervention aims to promote secure attachment in children by improving the sensitivity of their primary caregiver (usually the mother) while interacting with the child. Patterson's coercion theory describes how aggressive and antisocial behaviours develop in children and how ineffective parental discipline results in increasingly difficult and challenging child behaviour (see: Patterson, 1982; Reid, Patterson, Snyder, 2002). Although attachment theory and coercion theory originate from two separate research traditions, they actually have some important features in common. In the VIPP-SD program, attachment theory focuses on increasing parental sensitivity and responsiveness in daily parent-child interactions, whereas coercion theory is introduced to increase the parents' capacities of coercive discipline techniques in parent-child conflict situations. Combining both, parenting intervention is most effective when targeted at children and their parent(s), when the children are at a young age (1-5 years); and it is most effective in inhibiting the development of externalizing problems in children (see Mesman et al., 2008). 
As it is based on attachment theory, VIPP was first developed in a study of families with adopted children (Juffer et al., 2008). VIPP aims to enhance sensitive behavior in caregivers by providing personal video feedback with written information on how to respond sensitively in daily situations. The VIPP program was expanded to include feedback given to parents regarding maintaining discipline when interacting with their children. The resulting program was renamed Video-feedback Intervention to promote Positive Parenting and Sensitive Discipline (VIPP-SD) and focuses on parental sensitivity and discipline in play-related activities but also challenging parent-child interactions (Juffer, Bakermans-Kranenburg, van IJzendoorn, 2008). VIPP is usually directed at parents of infants, although VIPP-SD is successfully used with toddlers and preschool children up to 5 years old who were identified as being at a risk of developing externalized behavioral problems. The VIPP-SD program aims to enhance maternal observational skills, knowledge about parenting and development of young children, empathy for the child, sensitivity, and sensitive discipline strategies. The program is intended to influence parental sensitivity and parental sensitive discipline practices in order to make parents more responsive to the needs of the child and more consistent in their parenting (Juffer et al., 2008).

\section{Details of VIPP-SD}

VIPP-SD is similar to the video training methods developed by Biemans (1990) and later by McDonough (2004) but also uses guided self-observation through video feedback as developed by Erickson (Egeland \& Erickson, 2004 - see: Juffer, Bakermans-Kranenburg, van IJzendoorn, 2008). Video feedback is different from using videotaped model behaviour. During video training, parents do not identify themselves with the specific model of a parentchild dyad on the videotape. They remain focused on superficial differences in outlook and appearances of the dyad involved as compared to their own situation. On the other hand, the VIPP-SD program is most effective in changing parental behaviour when parents are provided with a mirror of their own daily interactions with their child (i.e. video material of them playing with their own child) (Juffer et al., 2008).

VIPP-SD, based on attachment and coercion theories, focuses on mirroring and discussing actual parent-child interactions in 6-7 1.5 hour sessions with individual families in their homes, aimed at preventing or reducing behavioural problems in children under 5. The aim of VIPP-SD is to record the whole range of the child's behaviour and the usual parental reactions to the child, during short episodes of 10 to 30 minutes in daily situations at home (for example: during play, clearing the toys, mealtime). The filming is done discreetly to enable a more natural parent-child interaction. The person recording the interactions should be unintrusive, and should not make any comments during the filming nor intervene when the child is distressed or frustrated. Everything is explained to the parent before filming starts (for example, that the filming will continue even when a child is annoyed or is crying, because such behaviour is a part of the child's behaviour repertoire).

The first visit just involves the recording of a video; each subsequent visit consists of making a new recording and a discussion of the previous week's recording. In the period between the two home visits, the intervener reviews the videotape and prepares comments on the child's behavior a the parents' reactions. A timestamped recording is used to facilitate the process of connecting the comments to the pictures. In preparation for the intervention, the intervener chooses fragments of the video that will illustrate general messages or themes and prepares a script for the intervention session, consisting of particular themes (for example exploration versus attachment behaviour) that will be discussed during the subsequent home visit.

During the next visit the videotape is shown to the parent and the positive and successful interaction is discussed using the pre-prepared comments. The intervention is implemented through standardized protocols over 6-7 home visits. The protocol defines themes and exercises for the parent and child for all visits. This feedback is prepared in advance by the intervener who has selected specific moments of the film to comment on and to discuss in the context of main issues of each session. The main themes that are successively discussed during the VIPP intervention are: 1) focusing on the children's behaviour and explaining the difference between exploration and attachment behaviour, 2) supporting the accurate perception of children's signals by verbalizing their facial expressions and nonverbal cues, 3) focusing on parental behaviour - in particular: explanation of adequate responses to babies' signals by discussing a "sensitivity chain": child signal $\rightarrow$ parental response $\rightarrow$ reaction of the child and 4 ) showing and encouraging parents to see positive and negative emotions in their child (see: Juffer et al., 2008, p. 15). Further VIPP-SD intervention, with an additional focus on sensitive discipline, was developed to support parents who have to handle problems with a child's behaviour. VIPP-SD can be characterized as a behaviourally oriented intervention using video feedback to promote adequate parental discipline strategies during parent-child interactions (Van Zeijl, Mesman, Van IJzendoorn et al., 2006). Each of the intervention sessions follows video feedback using VIPP themes (described above), but the intervener also elaborates on sensitive discipline components. In essence, VIPP-SD is enriched by additional themes over and above regular VIPP. The first four intervention sessions are scheduled at two-week intervals and examined for the following specific contents: (1) the difference between attachment and exploration behaviour, combined with distraction and induction as disciplinary strategies, as non-coercive responses to difficult child behaviour or situations that have the potential to cause conflict; (2) the perception of childrens' signals combined with positive reinforcement as a disciplinary strategy - praising the child for positive behaviour and ignoring negative attention seeking; (3) "chain of sensitivity" combined with sensitive timeouts as a disciplinary strategy for sensitively de-escalating 
temper tantrums; (4) the importance of sharing emotions, combined with empathy and understanding of the child as disciplinary strategies - in particular keeping consistent discipline and setting clear limits (see Juffer, BakermansKranenburg, Van IJzendoorn, 2008). Across these themes, several elements are crucial during the intervention process, including creating a pleasant atmosphere, acknowledging the mother as the expert on her own child, focusing on positive parent-child interaction and using the "speaking for the child" technique. "Speaking for the child" as a method of promoting a parent's perception of the child's signals, means talking to the parent from the child's perspective in order to draw the parent's attention to the child's more subtle signals (e.g. facial expressions or nonverbal cues) shown on the videotape.

According to those who received intervention, video feedback was more useful than written information about sensitive parenting and sensitive responding in daily situations (for example, about comforting a crying child or about playing together) as part of the intervention. However, most parents reported that at the end of intervention it was important that they received materials including video recordings and a personalised booklet reiterating the main themes discussed during the intervention, and including information about the child's development in the context of a particular (clinical) group of children, parenting tips, or suggestions for personal observations.

\section{Evidence of the efficiency of video feedback intervention}

Bakermans-Kranenburg, Van IJzendoorn, Juffer (2008) conducted a meta-analysis of several studies based on video feedback intervention (with more than 1800 families in the sample). The results of this analysis show statistically significant positive effects of video feedback interventions on attitudes the parenting behaviour attitude of parents and the development of the child (see: Juffer et al., 2008, p. 60-73). Parents become more skilled in interacting with their young child, experience fewer problems and take more pleasure in parenting. VIPP and VIPP-SD are used in more than 15 countries and the effectiveness of this method was demonstrated in 12 randomized trials in different countries. For example, researchers from the Netherlands tested the home-based intervention program VIPP-SD in a randomized controlled trial with 237 families screened for relatively high scores on externalizing behaviour in their 1-3 year old children (Van Zeijl, Mesman, Van IJzendoorn, Bakermans-Kranenburg, Juffer, Stolk, Koot, \& Alink, 2006). The study measured also family and personality components such as daily hassles, marital discord, wellbeing, difficult temperaments, externalizing problems and maternal attitudes toward sensitivity and sensitive discipline. The results indicated that the intervention had a significant impact on attitudes towards sensitivity and sensitive discipline. Subsequent studies showed that VIPP was effective in enhancing maternal sensitivity and in promoting infants' secure attachment in an Italian sample of dyads with primipara mothers (Cassibba et al., 2015). VIPP was effective for parents of children with a visual or visual-and-intellectual disability (VIPP-V) - (Overbeek et al., 2015). It was hypothesized that this attachmentbased intervention would support parents' interpretation and understanding of the behaviour of their child with a visual or visual-and-intellectual disability and respond to their child's signals in a sensitive way and, in doing so, improve the quality of parent-child interaction. Other studies conducted in the USA (Nazneen et al., 2015) proved to be effective in enhancing maternal attitudes towards sensitivity and in increasing positive interactions between a parent and a child with autism (VIPP-Auti). Negrão, Pereira, Soares \& Mesman (2014) suggested an additional reason for the effectiveness of VIPP-SD: VIPP$\mathrm{SD}$ was a valuable program for the enhancement of positive parent-child interactions in poor families struggling with many problems. This means that VIPP-SD contributes to the strengthening of families' resilience to the impact of socioeconomically disadvantageous environments. Results show that VIPP-SD support services provided to such poor families reduce intergenerational risk transmission. It is also worth noting that VIPP-SD increases sensitive parenting in mothers in ethnic minority (Yagmur et al., 2014). 76 Turkish minority families in the Netherlands were tested using the VIPP-TM (VIPP-Turkish Minorities). The VIPP-TM was effective in increasing maternal sensitivity and unintrusiveness, but not in enhancing discipline strategies. Applying newly learned sensitivity skills in discipline situations may take more time, especially in a cultural context that favours more authoritarian strategies. Yagmur, S, Mesman J, Malda M, Bakermans-Kranenburg MJ, Ekmekci H. (2014) conclude that the VIPP-SD program and its video-feedback approach can be successfully applied in immigrant families from a nonWestern cultural background.

Conclusions about the video-feedback intervention method Data from different studies, presented above, provides empirical evidence that VIPP-SD enhances positive parenting skills and focuses on finding positive behaviors in children and encouraging parent-child interaction. The method is used to focus on a specific issue to support parental sensitivity and discipline instead of on a variety of issues (e.g. a family's economic situation, support in school, etc.) and, finally, the method is related to a more positive development of children.

The main differences between VHT and VIPP-SD relate to the process of its execution based on video technique and the characteristics of the recipients of these methods. The new method - VIPP-SD - applies not only videotaping interactions of the parent and child but also providing very important video feedback intervention watching and discussing the videotape with the parent. Additionally, VIPP-SD, based on attachment and coercion theories, aims to enhance the parents' sensitivity and discipline strategies by increasing their observation skills, knowledge about development of young children as well as empathy with and understanding of their child. Focusing on the positive interactions serves to illustrate to the parent that they are able to react in a sensitive and competent way, 
fulfilling the child's attachment and exploration needs. By re-watching positive clips and repeating important messages regarding successful parenting, those positive skills are reinforced; while negative, insensitive parental behaviours are weakened. Video feedback provides parents the opportunity to focus on the signals coming from the child, thereby improving the parents' observational skills and empathy towards the child. VHT, as a tool for supporting development, may also be used by teachers, social workers or caregivers in facilities like care centres, nursing homes, hospitals, schools, prisons, and other resocialization institutions.

\section{Summary}

In summary, the goal of this article was to present a review of psychological methods based on video techniques used to support the development of small children and their families. This paper introduces the terminology and gives a review of the background of the current empirical knowledge about the process of development support in psychology. The VIPP-SD method described in the paper can be used as either: 1. A psycho-correctional supportive method for toddlers and the functioning of their families in case of disorders, 2. A psycho-stimulation method of optimization of the development of small children through the improvement of educational actions undertaken by the parents, 3. a preventive method aimed at improving the quality of parental observational skills and empathy towards the child. Building relations and bonds between the parent and the child, which is considered a key factor in the subsequent development of the child, is the main intention behind the interventions.

The long-term goal behind this publication is to encourage work on the cultural adaptation and implementation of the VIPP-SD method in Poland. The first steps have been already made in the Institute of Psychology in Bydgoszcz with the four-day VIPP-SD Training Course which took place in October 2015. A research team was assembled and empirical research on this method is in progress.

\section{References}

Ainsworth, M., Bell, S., Stayton, D. (1974). Infant-mother attachment and social development. In Richard, M. (Ed.) The integration of a child into a social world. London: Cambridge University Press.

Alink, L., Zeijl, J., Mesman, J., Van IJzendoorn, M., Bakermans-Kranenburg, M., Juffer, F., Stolk, M., \& Koot, H. (2006). Attachmentbased intervention for enhancing sensitive discipline in mother of 1-to 3-year-old children at risk for externalizing behavior problems: A randomized controlled trial. Journal of Consulting and Clinical Psychology, 74(6), 994-1005. doi: 10.1037/002-006X.74.6.994

Biemans, H. (1990). Video home training: theory method and organization of SPIN. In Kool et al. (Ed.). International seminar for innovative institutions. Ryswyck, The Netherlands, Ministry of Welfare Health and Culture.

Biemans, H., Hoogland, M. (1988). Video Home Training: Helping parents at home through video.

Bogdanowicz, M. (2010). Specjalne potrzeby edukacyjne oraz prawa uczniów i studentów z dysleksją w Europie. In Witkowska, B., Bidziński, K., Kurtka, P. (Eds.), Dzieci i młodzież ze specjalnymi potrzebami edukacyjnymi $w$ realizacji zadań rozwojowych. Kielce:
Uniwersytet Humanistyczno-Przyrodniczy im. Jana Kochanowskiego, Wyd. Gens, p. 15-33.

Bowlby, J. (1969). Attachment and loss. (Vol. 1). Attachment. New York: Penguin Books.

Brooks, J. (2008). Video Interaction Guidance: a practitioner's perspective. Community Pract., 81(9), 21-4.

Brzezińska, A. I. (2005). Psychologiczne portrety czlowieka. Gdańsk: GWP. Carr, A. (2009). Psychologia pozytywna. Poznań: Zysk i S-ka.

Cassibba, R., Castoro, G., Costantino, E., Sette, G., Van IJzendoorn, M. H. (2015). Enhancing maternal sensitivity and infant attachment security with video feedback: an exploratory study in Italy. Infant Ment Health J., 36(1), 53-61.

Cichocka, M. (1995). Psychologiczne determinanty pomocy psychologicznej dla człowieka starego. PWN, Poznań

Czapiński, J. (Ed.) (2005). Psychologia pozytywna. Warszawa: PWN.

De Wolff, M. S., \& Van IJzendoorn, M. H. (1997). Sensitivity and attachment: A meta-analysis on parental antecedents of infant attachment. Child Development, 68, 571-591.

Engeland, H. (2015). Video-feedback Intervention to promote Positive Parenting adapted to Autism (VIPP-AUTI): A randomized controlled trial. Autism, Jul, 19(5), 588-603.

Fukkink, R. G. (2008). Video feedback in widescreen: a meta-analysis of family programs. Clinical Psychology Review, Jul, 28(6), 904-916.

Gruszczyk-Kolczyńska, E. (2003). Co to znaczy wspomagać rozwój umysłowy dzieci niepełnosprawnych? In M. Kościelska, B. Aouil (Eds), Człowiek niepetnosprawny. Sprawność w niepetnosprawności. Bydgoszcz: Wydawnictwo AB.

Gruszczyk-Kolczyńska, E., Zielińska, E. (2000). Wspomaganie rozwoju umysłowego trzylatków i dzieci starszych wolniej rozwijających się. Warszawa: WSiP.

Gruszczyk-Kolczyńska, E., Zielińska, E. (2004). Wspomaganie rozwoju umystowego czterolatków i pięciolatków. Ksiązka dla rodziców, terapeutów i nauczycieli przedszkola. Warszawa: WSiP.

Joosen, K. J., Mesman, J., Bakermans-Kranenburg, M. J., \& van IJzendoorn, M. H. (2012). Maternal sensitivity to infants in various settings predicts harsh discipline in toddlerhood. Attachment \& Human Development, 14, 101-117.

Juffer, F., Bakermans-Kranenburg, M. J., \& van IJzendoorn, M. H. (Eds.). (2008). Promoting positive parenting: An attachment-based intervention. London: Lawrence Erlbaum Associates.

Juffer, F., Bakermans-Kranenburg, M. J., \& van IJzendoorn, M. H. (2014). Attachment-based interventions: Sensitive parenting is the key to positive parent-child relationships. In P. Holmes \& S. Farnfield (Eds.), The Routledge Handbook of Attachment: Implications and Interventions. New York: Routledge.

Kaja, B. M. (2004). Wspomaganie rozwoju - czyli dobrze mieć przyjaciół we wszystkich okolicznościach życia. In B. Kaja (Ed.), Wspomaganie rozwoju. Psychostymulacja i psychokorekcja (Vol. 6, p. 11-26). Bydgoszcz: Wydawnictwo Akademii Bydgoskiej.

Kaja, B. M. (2010). Psychologia wspomagania rozwoju. Zrozumieć świat życia czlowieka. Sopot: GWP.

Kielar-Turska, M. (1992). Jak wspomagać dziecko w poznawaniu świata? Warszawa: WSiP.

Kielar-Turska, M. (1997). Hermeneutyka a psychologia rozwojowa. Badanie nad rozumieniem przez dziecko świata i ludzkiego umysłu. In A. Gałdowa (red.), Hermeneutyka a psychologia. Kraków: Wydawnictwo UJ.

Kielar-Turska, M. (2003). Analiza pola semantycznego terminów związanych ze wspomaganiem rozwoju. In B. Kaja (red.), Wspomaganie rozwoju. Psychostymulacja i psychokorekcja. (Vol. 5, p. 11-25). Bydgoszcz: Wydawnictwo Akademii Bydgoskiej.

Kennedy, H., Landor, M., \& Todd, L. (2010) Video Interaction Guidance as a method to promote secure attachment Educational and Child Psychology, Vol. 27, No. 3.

Keulen, T., \& Van Loden, A. (1999). An Evaluation Report on Video Home Training. SPIN USA

Kościelska, M. (2002). Kierunki rozwoju psychologii klinicznej dziecka w Polsce. In B. Kaja (red.), Wspomaganie rozwoju. Psychostymulacja i psychokorekcja. (Vol. 4, p. 9-16). Bydgoszcz: Wydawnictwo Akademii Bydgoskiej.

Kowalik, S. (2000). Wspomaganie rozwoju w procesie starzenia się. B. Kaja (red.), Wspomaganie rozwoju. Psychostymulacja i psychokorekcja. (Vol. 2, p. 65-81). Bydgoszcz: Wydawnictwo Akademii Bydgoskiej. 
Miś L., Kujawa M., Frysztacki, M. (1999). Video-Home Training jako metoda pracy z rodzinami. In Praca socjalna i pomoc społeczna, Rzeszów.

Negrão, M., Pereira, M., Soares, I., \& Mesman, J. (2014). Enhancing positive parent-child interactions and family functioning in a poverty sample: a randomized control trial; Attachment \& Human Development, Vol. 16, No. 4, 315-328.

Overbeek, M., Sterkenburg, P. S., Kef, S., Schuengel, C. (2015). The effectiveness of VIPP-V parenting training for parents of young children with a visual or visual-and-intellectual disability: study protocol of a multicenter randomized controlled trial. Trials, 9(16), 401.

Obuchowska, I. (1993). Dziecko niepełnosprawne w rodzinie. Zarys problemów. In R. Ossowski (Ed.), Sytuacja życiowa dziecka niepetnosprawnego w rodzinie, Bydgoszcz: Wydawnictwo WSP

Obuchowska, I. (1997). Wspomaganie rozwoju emocjonalnego: refleksje i propozycje. In B. Kaja (Ed.), Wspomaganie rozwoju. Psychostymulacja i psychokorekcja. (Vol. 1, p. 35-48). Bydgoszcz: Wydawnictwo Akademii Bydgoskiej.

Patterson, G. R. (1982). Coercive family processes. Eugene, OR: Castalia.

Pilecka, W. (2012). Sens wspomagania rozwoju dziecka z niepełnosprawnością złożoną. In D. Wolska, A. Mikrut (Ed.), Annales Universitatis Pedagogicae Cracoviensis. Studia Pedagogica II, (p. 18-26) Kraków: Wydawnictwo Naukowe UP.

Pilecka, W., Pilecki J. (1996). Stymulacja psychoruchowego rozwoju dzieci o obniżonej sprawności umystowej. Kraków: Wydawnictwo Naukowe WSP.

Poslawsky, I. E., Naber, F., Bakermans-Kranenburg, M. J., van Daalen, E., Puślecki, W. (Ed.) (2008). Wspieranie rozwoju dzieci w procesie wczesnej edukacji - praca zbiorowa. Wrocław: Wydawnictwo Naukowe Dolnośląskiej Szkoły Wyższej.

Reid, J. B., Patterson, G. R., \& Snyder, J. (2002). Antisocial behavior in children and adolescents: a developmental analysis and model for intervention. Washington, DC: American Psychological Association.

Straś-Romanowska, M. (2003). Wspomaganie ludzkiego rozwoju w świetle założeń dotyczących jego ukierunkowania. In Kaja, B. (Ed.),
Wspomaganie rozwoju. Psychostymulacja i psychokorekcja (Vol. 5 , p. 40-55). Bydgoszcz: Wydawnictwo Akademii Bydgoskiej.

Stolk, M. N., Mesman, J., van Zeijl, J., Alink, L. R. A., BakermansKranenburg, M. J., van IJzendoorn, M. H.; Koot, H. M. (2008). Early parenting intervention aimed at maternal sensitivity and discipline: A process evaluation. Journal of Community Psychology, 36, 780-797.

Tamis-LeMonda, C. S., Bornstein, M. H., \& Baumwell, L. (2001). Maternal responsiveness and children's achievement of language milestones. Child Development, 72, 748-767.

Tarabulsy, G. M., Pascuzzo, K., Moss, E., St-Laurent, D., Bernier, A., Cyr, C., \& Dubois-Comtois, K. (2008). Attachment-based intervention for maltreating families. American Journal of Orthopsychiatry, $78,322-332$.

Trempała, J. (2014). Psychologia rozwoju czlowieka. Warszawa: PWN.

Trevarthen, C. and Hubley, P. (1978). Secondary intersubjectivity: Confidence, confiding and acts of meaning in the first year. In Lock, A. (Ed.) Action, Gesture and Symbol: The Emergence of Language. (pp. 183-229) London, UK: Academic Press.

Trevarthen, C. (1979). Communication and cooperation in early infancy: a description of primary intersubjectivity. In Bullowa, M. (Ed), Cambridge.

Twardowski, A. (2012). Wczesne wspomaganie rozwoju dzieci z niepetnosprawnościami w środowisku rodzinnym. Poznań: Wydawnictwo Naukowe UAM.

Van Zeijl, J., Mesman, J., van IJzendoorn, M. H., Bakermans-Kranenburg, M. J., Juffer, F., Stolk, M. N., Alink, L. R. (2006). Attachment-based intervention for enhancing sensitive discipline in mothers of 1- to 3-year-old children at risk for externalizing behaviour problems: A randomized controlled trial. Journal of Consulting and Clinical Psychology, 74, 994-1005.

Yagmur, S., Mesman, J., Malda, M., Bakermans-Kranenburg, M. J., Ekmekci, H. (2014). Video-feedback intervention increases sensitive parenting in ethnic minority mothers: a randomized control trial. Attachment \& Human Dev., 16(4), 371-86. 